\title{
Effects of Biochar Combined with Nitrogen Fertilizer Reduction on Rapeseed Yield and Soil Aggregate Stability in Upland of Purple Soils
}

\author{
Xiaoqin Tian ${ }^{1,2,3,4}$, Zhuo $\mathrm{Li}^{4}$, Longchang Wang ${ }^{1,2,3, *(\mathbb{C})}$, Yifan Wang ${ }^{1,2,3}$, Biao $\mathrm{Li}^{1,2,3}$, \\ Meichun Duan 1,2,3 and Bangyan Liu 1,2,3 \\ 1 College of Agronomy and Biotechnology, Southwest University, Chongqing 400715, China; \\ a865257025@163.com (X.T.); w951352241@email.swu.edu.cn (Y.W.); libiao08.05@163.com (B.L.); \\ duanmc@swu.edu.cn (M.D.); bangyan_liu@126.com (B.L.) \\ 2 Key Laboratory of Eco-environments in Three Gorges Reservoir Region, Ministry of Education, \\ Chongqing 400715, China \\ 3 Engineering Research Center of South Upland Agriculture, Ministry of Education, Chongqing 400715, China \\ 4 Crop Research Institute, Sichuan Academy of Agriculture Sciences, Chengdu 610066, China; \\ lizhuo_2000@sina.com \\ * Correspondence: wanglc@swu.edu.cn
}

Received: 12 December 2019; Accepted: 28 December 2019; Published: 31 December 2019

check for updates

\begin{abstract}
Reduction of soil fertility and production efficiency resulting from excessive application of chemical fertilizers is universal in rapeseed-growing fields. The main objective of our study was to assess the effects of biochar combined with nitrogen fertilizer reduction on soil aggregate stability and rapeseed yield and to identify the relationship between yield and soil aggregate stability. A two-factor field experiment (2017-2019) was conducted with biochar $\left(0\left(C_{0}\right), 10\left(C_{10}\right), 20\left(C_{20}\right)\right.$ and 40 t.ha ${ }^{-1}$ $\left.\left(\mathrm{C}_{40}\right)\right)$ and nitrogen fertilizer $\left(180\left(\mathrm{~N}_{100}\right), 144\left(\mathrm{~N}_{80}\right)\right.$ and $\left.108 \mathrm{~kg} \mathrm{~N} \cdot \mathrm{ha}^{-1}\left(\mathrm{~N}_{60}\right)\right)$. Experimental results indicated that under $\mathrm{N}_{100}$ and $\mathrm{N}_{80}$ treatments, $\mathrm{C}_{10}$ significantly increased the macro-aggregates $\left(\mathrm{R}_{0.25}\right)$, mean weight diameter (MWD) and geometric mean diameter (GMD) of soil water stable aggregate by $14.28 \%-15.85 \%, 14.88 \%-17.08 \%$ and $36.26 \%-42.22 \%$, respectively, compared with $\mathrm{C}_{0}$. Besides, the overall difference of the soil water-stable aggregate content in 2-5 mm size range among nitrogen treatments was significant under the application of $C_{10}$, which increased by $17.04 \%-33.04 \%$ compared with $\mathrm{C}_{0}$. Total organic carbon (TOC) in $\mathrm{R}_{0.25}$ of soil mechanical-stable aggregates was basically all increased after biochar application, especially in $0.25-1 \mathrm{~mm}$ and $1-2 \mathrm{~mm}$ aggregates, and had an increasing trend with biochar increase. $\mathrm{C}_{10}$ significantly increased rapeseed yield by $22.08 \%-45.65 \%$ in 2019, compared with $\mathrm{C}_{0}$. However, the reduction of nitrogen fertilizer reduced the two-year average rapeseed yield, which decreased by $11.67 \%-31.67 \%$ compared with $\mathrm{N}_{100}$. The highest yield of rapeseed was obtained by $\mathrm{N}_{100} \mathrm{C}_{10}$ in two consecutive years, which had no statistical difference with $\mathrm{N}_{80} \mathrm{C}_{10}$. However, the two-year yields of $\mathrm{N}_{80} \mathrm{C}_{10}$ were all higher than those of $\mathrm{N}_{100} \mathrm{C}_{0}$ with increase rate of $16.11 \%$, and which would reduce $35.43 \%$ nitrogen fertilizer in the case of small yield difference, compared with the highest yield $\left(2.67 \mathrm{t} \cdot \mathrm{ha}^{-1}\right)$ calculated by multi-dimensional nonlinear regression models. The regression analysis indicated $\mathrm{R}_{0.25}$, MWD and GMD had the strong positive associations with rapeseed yield, whereas percentage of aggregate destruction $\left(\mathrm{PAD}_{0.25}\right)$ had a significant negative correlation with rapeseed yield. This study suggests that the application of biochar into upland purple soil could improve soil structure, increase the content of TOC in macro-aggregates under nitrogen fertilizer reduction as well as replace part of nitrogen fertilizer to achieve relatively high rapeseed yield.
\end{abstract}

Keywords: upland purple soil; biochar; rapeseed yield; soil aggregate; nitrogen fertilizer 


\section{Introduction}

Soil aggregates are the material basis of soil fertility by reducing soil erosion, adjusting air permeability, water infiltration and nutrient cycling [1,2] and contributing to soil functions. It regulates soil physical, chemical and biological processes, and thus affects the function of soil organic matter and fertility [3]. At the same time, it is also largely responsible for soil structural stability, which is fundamental for improving crop yield, preventing soil degradation and reducing environmental pollution [4]. The quantity, distribution and spatial arrangement of soil aggregates of various sizes have an important role in controlling soil pore distribution, determining soil hydraulic properties and permeability and influencing soil microbial activity as well as nutrients maintenance and supply [5]. However, soil aggregation is controlled by many factors, such as soil organic carbon (SOC), soil animals, microorganisms and plant root systems. The soil aggregates and SOC are interdependent and closely linked and interrelated. Soil organic matter is one of the major constituents in the formation of aggregates by serving as a major binding agent in the formation and stabilization of aggregates, while on the other hand soil aggregates protect soil organic matter (SOM) from mineralization because they are less vulnerable to microbial, enzymatic and physical degradation [6]. As one of the main producing areas of rapeseed in China, the annual rapeseed planting area and output in southwest regions account for $20 \%-30 \%$ of the country. Since the 1970 s, some unreasonable agricultural management measures with excessive use of chemical fertilizers and imbalance of input ratio of nitrogen, phosphorus and potassium resulted in the depletion of soil organic carbon, breakdown of soil structure and decline of soil productivity in uplands in southwest China [7]. In 2010, China has become the world's largest chemical fertilizer consumption country. Nitrogen fertilizer accounts for about $60 \%$ of the chemical fertilizer and the annual nitrogen fertilizer consumption accounts for more than $35 \%$ of the world's total consumption, and it is increasing year by year. Therefore, it is very urgent to explore economic and effective fertilization measures for improving soil structure, soil fertility and crop productivity in upland purple soil in southwest China.

Crop straw is a kind of renewable bio-resource. It is rich in organic carbon, nitrogen, phosphorus, potassium and other mineral nutrients. However, the discarding and burning of straw will cause environmental pollution and recourse waste. Recently, biochar, a significant carbonaceous component arising from the incomplete combustion of various organic precursors such as crop straw, has attracted increasing attention in China as its role in achieving the sustainable development of resources, environment and agriculture. Various studies have shown the beneficial effects of biochar as a soil amendment to reduce greenhouse gas emission and improve heavy metal pollution $[8,9]$. In addition, biochar can enhance soil microorganism activity and indirectly change the mineralization rate of SOC, which in turn influences the formation process of soil aggregates [6]. For example, Joseph et al. [10] reported that biochar significantly improved water-stable aggregate stability in albic soils and the biochar application had positive effects on mean weight diameter (MWD) of water-stable aggregates, SOC and total nitrogen content (TN) within aggregates. Hence, biochar has been used not only as an amendment to maximize the efficient use of straw nutrients, but also as an important technical means to improve the soil environment, increase crop yield and quality, and achieve fertilizer reduction and efficiency increase. However, no consistent conclusions currently exist on the effects of biochar on the amount and stability of soil aggregates in previous studies in response to changing biochar species, biochar dosage or soil conditions. Joseph et al. [10] found an increase in aggregate formation when biochar was applied to albic soils. Contrariwise, Zhou et al. [11] did not observe any improvement in soil aggregate in sandy loam soil after sole biochar application. Moreover, Heikkinen et al. [12] reported that properties of the biochar depended on feedstock type, with significantly improved aggregate stability and reduced colloid detachment with hydrothermal carbonization biochars, but no effect with slow pyrolysis biochars. These differences found in soil aggregate after biochar application may be related to many complex interactions and bonding mechanisms of biochar, clay minerals and native SOM [13]. In China, research on effect of biochar on soil aggregates have been carried out on a wide range of soil types, such as ferrallitic soil [14], leached soil [15] and semi-hydromorphic soil [16,17]. 
However, for upland lithomorphic soil (purple soils), the effect of biochar based on nitrogen fertilizer reduction on soil aggregate stability is not well known. Besides, based on the short-term conditions, whether the biochar can replace nitrogen fertilizer still lacks sufficient practice verification.

Therefore, the aim of this study was to (1) assess the impacts of biochar combined with nitrogen reduction on soil mechanical and water-stable aggregate distribution, soil aggregate stability and total organic carbon (TOC) content in different sizes of mechanical aggregates in upland of purple soils; and (2) determine whether the application of biochar can replace $20 \%-40 \%$ nitrogen fertilizers to increase rapeseed production in upland of purple soils in southwestern China. Experimental results are expected to provide important theoretical basis and technical support for the rational use of biochar in rapeseed production in upland of purple soils in southwestern China, improving soil quality and achieving high yield and high efficiency of rapeseed.

\section{Materials and Methods}

\subsection{Study Site}

The two-years field experiments were conducted during the two successive rapeseed seasons of 2017-2018 and 2018-2019 in Jiangnan village, Yunyang country, Chongqing, China (108 $54^{\prime} \mathrm{E}, 30^{\circ} 55^{\prime}$ $\mathrm{N}$, elevation $700 \mathrm{~m}$ ). The experimental field was located in a subtropical monsoon humid climate zone. The mean annual temperature and rainfall were $18.4^{\circ} \mathrm{C}$ and $1100.1 \mathrm{~mm}$, respectively, with rainfall mainly occurring during June to August. The test soil is purple soil, and its basic properties were as follows: pH 7.29 (soil:water of 1:5), total N $0.94 \mathrm{~g} \cdot \mathrm{kg}^{-1}$, total C $7.14 \mathrm{~g} \cdot \mathrm{kg}^{-1}$, available $\mathrm{N} 37.45 \mathrm{mg} \cdot \mathrm{kg}^{-1}$, available P $2.36 \mathrm{mg} \cdot \mathrm{kg}^{-1}$ and available $\mathrm{K} 72.58 \mathrm{mg} \cdot \mathrm{kg}^{-1}$, respectively.

\subsection{Biochar Amended}

A commercially produced biochar (purchased from the Nanjing Qinfeng Straw Technology Co., Ltd. (Nanjing, China)), which was made by pyrolysis of the rice (Oryza sativa L.) straw with limited oxygen supply at $500{ }^{\circ} \mathrm{C}$ for $2 \mathrm{~h}$, was used. Its properties were as follows: total $\mathrm{N} 0.61 \mathrm{~g} \cdot \mathrm{kg}^{-1}$, total P $1.99 \mathrm{~g} \cdot \mathrm{kg}^{-1}$, total K $27.15 \mathrm{~g} \cdot \mathrm{kg}^{-1}$, total C $537.97 \mathrm{~g} \cdot \mathrm{kg}^{-1}$ and $\mathrm{pH} 8.70$.

\subsection{Field Experiment}

A two-factor and multiple-level experiment was performed. The first factor was the application of biochar, including: $0 \mathrm{t} \cdot \mathrm{ha}^{-1}\left(\mathrm{C}_{0}\right), 10 \mathrm{t} \cdot \mathrm{ha}^{-1}\left(\mathrm{C}_{10}\right), 20 \mathrm{t} \cdot \mathrm{ha}^{-1}\left(\mathrm{C}_{20}\right)$ and $40 \mathrm{t} \cdot \mathrm{ha}^{-1}\left(\mathrm{C}_{40}\right)$. Nitrogen fertilizer application was the second factor, including: 1) conventional application rate $\left(180 \mathrm{~kg} \mathrm{~N} \cdot \mathrm{ha}^{-1} ; \mathrm{N}_{100}\right)$; 2) $80 \%$ of conventional application rate $\left(144 \mathrm{~kg} \mathrm{~N} \cdot \mathrm{ha}^{-1} ; \mathrm{N}_{80}\right)$ and 3$) 60 \%$ of conventional application rate $\left(108 \mathrm{~kg} \mathrm{~N} \cdot \mathrm{ha}^{-1} ; \mathrm{N}_{60}\right)$. Winter rapeseed (Sanxiayou No. 5) was used in the experiment. Twelve treatments $(4 \times 3)$ were setup in a randomized block design with three replications. Each plot was $3 \mathrm{~m} \times 6 \mathrm{~m}$ with a border ( $0.5 \mathrm{~m}$ wide) between plots. Following the local conventional fertilization, the fertilizer $\mathrm{N}$ of urea was applied according to different nitrogen fertilizer treatments during the rapeseed season, $40 \%$ of which was as a base fertilizer prior to seeding and the left $60 \%$ at the bolting stage. Both pure $\mathrm{P}$ and $\mathrm{K}$ for rapeseed were as a basal application of $90 \mathrm{~kg} \mathrm{P}_{2} \mathrm{O}_{5} \mathrm{ha}^{-1}$ and $90 \mathrm{~kg}$ $\mathrm{K}_{2} \mathrm{O}^{-1}$ through calcium superphosphate and potassium chloride, respectively, which were applied before ploughing and sowing. Biochar was added to the soil surface just at the beginning of the trial and thoroughly mixed with a depth of approximately $15 \mathrm{~cm}$, and no further biochar was added for the duration of the study. Agricultural managements were same as those used on local farmlands. Rapeseed was planted on 21 October 2017 and on 16 October 2018, and was harvested on 1 May 2018 and on 1 May 2019.

\subsection{Soil Sampling and Analysis}

Soil samples $(0-20 \mathrm{~cm})$ were collected at five points in each plot and then mixed (mass was about $1.5 \mathrm{~kg}$ ) on 4 May 2019, and were sealed in plastic bags and transported to the laboratory as soon 
as possible. Soil samples were broken into small pieces to pass a $10 \mathrm{~mm}$ sieve and then air-dried, and used for soil aggregate analysis. Basic soil properties and biochar properties were determined using the methods suggested by Teng et al. [18]. Soil $\mathrm{pH}$ and biochar $\mathrm{pH}$ was determined by a glass electrode (solid-to-water ratio of 1:2.5), organic $\mathrm{C}$ in soil and biochar by dichromate oxidation with heating $\left(\mathrm{K}_{2} \mathrm{Cr}_{2} \mathrm{O}_{7}-\mathrm{H}_{2} \mathrm{SO}_{4}\right)$, total $\mathrm{N}$ in biochar by the semi-micro Kjeldahl method, total $\mathrm{P}$ in biochar by a phosphomolybdic acid blue color method, total $\mathrm{K}$ in biochar by the $\mathrm{NaOH}$ melting-flame photometric method, alkali-hydrolyzable $\mathrm{N}$ in soil by the alkali solution diffuse method, available $\mathrm{P}$ in soil by the $\mathrm{NaHCO}_{3}$ ( $\mathrm{pH}$ 8.5) extraction-phosphomolybdate blue spectro-photometric method and available $\mathrm{K}$ in soil by the $\mathrm{NH}_{4} \mathrm{OAc}$ extraction-flame photometer method. At maturing stage in 2018 and 2019, rapeseed in each plot was separately harvested to measure seed yield.

\subsection{Aggregate Separation}

A combination of wet and dry sieving methods was employed for soil aggregate classification [5]. The dry sieving method was used to determine soil mechanical-stable aggregate size distribution (ASD). To do so, $500 \mathrm{~g}$ air-dried soil samples were dry-sieved using a stainless-steel vibrating sieve set. Mechanical-stable aggregates of various sizes $(>5,2-5,1-2,0.25-1$ and $<0.25 \mathrm{~mm}$ ) were obtained through dry sieving. Soil aggregates from each sieve were analyzed for organic carbon content. Wet sieving method was used to determine soil water-stable ASD. Briefly, $200 \mathrm{~g}$ air-dried soil was weighed and placed on the first sieve composed of 5, 2, 1 and $0.25 \mathrm{~mm}$ mesh sieves in a water bucket and was gently moistened for $5 \mathrm{~min}$ with distilled water at room temperature. The aggregates of various sizes were separated by moving the sieve vertical with an amplitude of $3 \mathrm{~cm}$ at a speed of 30 strokes.min ${ }^{-1}$ for $2 \mathrm{~min}$ after pre-wetting. After sieving, all aggregate-size fractions remaining on each sieve were collected and dried at $60^{\circ} \mathrm{C}$, and then weighed.

For the determination of ASD of soil mechanical-stable aggregates and water-stable aggregates, the weight ratio of aggregates of each sieve $(>5,2-5,1-2,0.25-1$ and $<0.25 \mathrm{~mm})$ to the total weight of aggregates was calculated. Aggregate stability indices were denoted by $>0.25 \mathrm{~mm}$ soil aggregates $\left(\mathrm{R}_{0.25}\right)$, soil aggregate destruction $\left(\mathrm{PAD}_{0.25}\right)$, mean weight diameter (MWD) and mean geometric diameter (GMD) [5].

$$
\begin{gathered}
\mathrm{DR}_{0.25}\left(\mathrm{WR}_{0.25}\right)=\frac{\sum_{i=1}^{n}\left(w_{i>0.25}\right)}{\sum_{i=1}^{n}\left(w_{i}\right)} \times 100 \%, \\
\mathrm{D}-\mathrm{MWD}(\mathrm{W}-\mathrm{MWD})=\sum_{i=1}^{n}\left(\overline{d_{i}} w_{i}\right), \\
\mathrm{D}-\mathrm{GMD}(\mathrm{W}-\mathrm{GMD})=\exp \left[\frac{\sum_{i=1}^{n} m_{i} \ln \overline{d_{i}}}{\sum_{i=1}^{n} m_{i}}\right], \\
\text { PAD0.25 }=\frac{\mathrm{DR}_{0.25}-\mathrm{WR}_{0.25}}{\mathrm{DR}_{0.25}} \times 100 \%,
\end{gathered}
$$

where $\mathrm{DR}_{0.25}$ and $\mathrm{WR}_{0.25}$ are the proportion of $>0.25 \mathrm{~mm}$ soil mechanical-stable aggregates and water-stable aggregates, respectively; D-MWD and W-MWD are the mean weight diameter of mechanical-stable aggregates and water-stable aggregates $(\mathrm{mm})$, respectively; D-GMD and W-GMD are the mean geometric diameter of mechanical-stable aggregates and water-stable aggregates $(\mathrm{mm})$, respectively; $m_{i}$ is mass in size fraction $i$; and $w_{i}$ is the proportion (\%) of the total sample mass in size fraction $i$ and $\overline{d_{i}}$ is mean diameter of size fraction $i$.

\subsection{Statistical Analysis}

Two-way analysis of variance (ANOVA) was performed by SPSS 17.0 (SPSS Inc., Chicago, IL, USA). Means were tested using the multiple-comparison performed by least significant difference 
(LSD) at $p<0.05$. Excel 2018 (Office Software, Inc., Beijing, China) and SigmaPlot 12.5 (Systat Software, Inc., Erkrath, Germany) software were used for drawing figures.

\section{Results}

\subsection{Effect of Biochar and Nitrogen Fertilizer on Soil Aggregate Content and Distribution}

After a two-year field experiment, differences in the content and distribution of soil aggregates were observed among the different biochar and nitrogen fertilizer treatments (Tables 1 and 2). As shown in Table 2, The particle size distribution of soil mechanical-stable aggregates for each nitrogen treatment was basically the same, mostly concentrated within the size ranges of $>5 \mathrm{~mm}$ and $2-5 \mathrm{~mm}$, and the content of soil mechanical-stable aggregates in size of 1-2 mm was the least. For each nitrogen treatment, biochar increased the soil mechanical-stable aggregate content in 1-2 $\mathrm{mm}$ size range, especially at the optimal dosage of $10 \mathrm{t} \cdot \mathrm{ha}^{-1}$, and $\mathrm{N}_{60} \mathrm{C}_{10}$ significantly increased it by $46.00 \%$ compared to $\mathrm{N}_{60} \mathrm{C}_{0}$ $(p<0.05)$. This is mainly due to the reduction of percentages of soil mechanical-stable aggregates in size of $<0.25 \mathrm{~mm}$, with a decrease of $28.93 \%-32.58 \%$. These results showed that the application of 10 th ha ${ }^{-1}$ biochar for each nitrogen treatment could contribute to soil mechanical-stable aggregates with a change from $<0.25 \mathrm{~mm}$ to $1-2 \mathrm{~mm}$.

It can also be seen from Table 2 that biochar increased the soil water-stable aggregate content in $>5 \mathrm{~mm}$ size range for each nitrogen treatment, and the difference between $\mathrm{N}_{80} \mathrm{C}_{40}$ and $\mathrm{N}_{80} \mathrm{C}_{0}, \mathrm{~N}_{60} \mathrm{C}_{20}$ and $\mathrm{N}_{60} \mathrm{C}_{0}, \mathrm{~N}_{60} \mathrm{C}_{40}$ and $\mathrm{N}_{60} \mathrm{C}_{0}$ was significant $(p<0.05)$, with an increase of $24.43 \%-35.80 \%$. In addition, the content of soil water-stable aggregates of $2-5 \mathrm{~mm}$ generally increased firstly and then decreased with the increase of biochar, but decreased slightly with the decrease of nitrogen fertilizer. The overall difference of the soil water-stable aggregate content in 2-5 $\mathrm{mm}$ size range for each nitrogen treatment was significant $(p<0.05)$ at the application of $10 \mathrm{t} \cdot \mathrm{ha}^{-1}$ biochar, with the increase of $17.04 \%-33.04 \%$ compared with no biochar. This is also mainly due to the reduction of percentages of soil water-stable aggregates in size of $<0.25 \mathrm{~mm}$, with a decrease of $14.49 \%-30.88 \%$. This indicated that biochar could effectively increase the content of soil water-stable aggregates in $>5 \mathrm{~mm}$ and $2-5 \mathrm{~mm}$ size ranges for each nitrogen treatment, especially at the optimal dosage of $10 \mathrm{t} \cdot \mathrm{ha}^{-1}$, and it could significantly promote the formation of soil water-stable aggregates of $2-5 \mathrm{~mm}$ size range from $<0.25 \mathrm{~mm}$ size range.

\subsection{Effect of Biochar and Nitrogen Fertilizer on Soil Stability Index}

Except for $\mathrm{PAD}_{0.25}$, for each nitrogen fertilizer treatment, the effects of biochar on other soil stability index $\left(\mathrm{DR}_{0.25}, \mathrm{WR}_{0.25}\right.$, D-MWD, D-GMD, W-MWD and W-GMD) reached a highly significant level $\left(p<0.01\right.$; Table 1). After the application of biochar, the difference in $\mathrm{DR}_{0.25}$ was not significant for the each nitrogen fertilizer treatment $(p>0.05)$, but biochar increased $W_{0.25}$ in which $C_{10}$ significantly increased it $(p<0.05)$ by $15.85 \%$ and $14.28 \%$ for the $\mathrm{N}_{100}$ and $\mathrm{N}_{80}$ treatments, respectively, compared with $\mathrm{C}_{0}$ (Table 3).

As shown in Table 3, compared with no biochar, non-significant differences in the D-MWD and D-GMD were observed after the application of biochar for the each nitrogen fertilizer treatment $(p>0.05)$. However, biochar increased W-MWD and W-GMD for the each nitrogen fertilizer treatment, and compared with the $\mathrm{C}_{0}$, the W-MWD and W-GMD of $\mathrm{C}_{10}$ for the $\mathrm{N}_{100}$ treatment significantly increased by $17.08 \%$ and $42.22 \%$, respectively $(p<0.05)$; and the W-MWD and W-GMD of $\mathrm{C}_{10}$ for the $\mathrm{N}_{80}$ treatment significantly increased by $14.88 \%$ and $36.26 \%$, respectively $(p<0.05)$. 
Table 1. Results of two-factor ANOVA (F values) with biochar and nitrogen fertilizer as independent factors for changes in soil attributes.

\begin{tabular}{|c|c|c|c|c|c|c|c|c|c|c|c|c|c|c|c|c|c|}
\hline \multirow{2}{*}{ Factors } & \multicolumn{5}{|c|}{ Soil Aggregates by Dry Sieving } & \multicolumn{5}{|c|}{ Soil Aggregates by Wet Sieving } & \multirow{2}{*}{$\mathrm{DR}_{0.25}$} & \multirow{2}{*}{ D-MWD } & \multirow{2}{*}{ D-GMD } & \multirow{2}{*}{$\mathrm{WR}_{0.25}$} & \multirow{2}{*}{ W-MWD } & \multirow{2}{*}{ W-GMD } & \multirow{2}{*}{ PAD $_{0.25}$} \\
\hline & $>5$ & $2-5$ & $1-2$ & $0.25-1$ & $<0.25$ & $>5$ & $2-5$ & $1-2$ & $0.25-1$ & $<0.25$ & & & & & & & \\
\hline $\mathrm{N}$ & ns & ns & ns & $*$ & ns & ns & $* *$ & ns & ns & * & ns & ns & ns & $*$ & ns & ns & ns \\
\hline C & $* *$ & ns & ** & ns & $* *$ & $* *$ & $* *$ & $* *$ & ns & ** & $* *$ & $* *$ & ** & $* *$ & $* *$ & $* *$ & ns \\
\hline $\mathrm{N} \times \mathrm{C}$ & ns & ns & ns & ns & ns & ns & ns & ns & ns & ns & ns & ns & ns & ns & ns & ns & ns \\
\hline
\end{tabular}

Note: The "ns" means the difference is not significant; the "** and “**" indicate significant difference at $p<0.05$ and $p<0.01$, respectively. N means nitrogen fertilizer; $\mathrm{C}$ means biochar; $\mathrm{WR}_{025}$ means content of $>0.25 \mathrm{~mm}$ soil water-stable aggregates; $\mathrm{DR}_{025}$ means content of $>0.25 \mathrm{~mm}$ soil mechanical-stable aggregates; W-MWD means mean weight diameter of water-stable aggregates; D-MWD means mean weight diameter of mechanical-stable aggregates; W-GMD means geometric mean diameter of water-stable aggregates; D-GMD means geometric mean diameter of mechanical-stable aggregates; $\mathrm{PAD}_{0.25}$ means $>0.25 \mathrm{~mm}$ percentage of aggregate destruction.

Table 2. The effect of biochar and nitrogen fertilizer on content and distribution of soil aggregates.

\begin{tabular}{|c|c|c|c|c|c|c|c|c|c|c|c|}
\hline \multicolumn{2}{|c|}{ Treatments } & \multicolumn{10}{|c|}{ Aggregate Size (mm), \% } \\
\hline \multirow{2}{*}{ Pure N (kg.ha- ${ }^{-1}$ ) } & \multirow{2}{*}{ Biochar $\left(\mathrm{t} \cdot \mathrm{h} \mathrm{a}^{-1}\right)$} & \multicolumn{5}{|c|}{ Dry Sieving } & \multicolumn{5}{|c|}{ Wet Sieving } \\
\hline & & $>5$ & $2-5$ & $1-2$ & $0.25-1$ & $<0.25$ & $>5$ & $2-5$ & $1-2$ & $0.25-1$ & $<0.25$ \\
\hline \multirow[t]{3}{*}{$180\left(\mathrm{~N}_{100}\right)$} & $0\left(\mathrm{C}_{0}\right)$ & $54.0 \pm 1.8 \mathrm{Aa}$ & $22.5 \pm 1.1 \mathrm{Aa}$ & $5.0 \pm 0.4 \mathrm{Aa}$ & $6.5 \pm 0.3 \mathrm{Aa}$ & $12.1 \pm 0.4 \mathrm{Aab}$ & $17.6 \pm 1.3 \mathrm{Aa}$ & $23.0 \pm 2.0 \mathrm{Ab}$ & $8.7 \pm 0.7 \mathrm{Aa}$ & $16.7 \pm 1.2 \mathrm{Aa}$ & $34.0 \pm 3.4 \mathrm{Aa}$ \\
\hline & $20\left(\mathrm{C}_{20}\right)$ & $51.2 \pm 1.8 \mathrm{Aa}$ & $24.4 \pm 1.4 \mathrm{Aa}$ & $5.3 \pm 0.4 \mathrm{Aa}$ & $6.7 \pm 0.5 \mathrm{Aa}$ & $12.5 \pm 0.3 \mathrm{Aa}$ & $21.0 \pm 0.9 \mathrm{Aa}$ & $23.4 \pm 1.4 \mathrm{Ab}$ & $7.8 \pm 1.4 \mathrm{Aa}$ & $17.7 \pm 0.5 \mathrm{Aa}$ & $30.1 \pm 3.5 \mathrm{Aab}$ \\
\hline & $40\left(\mathrm{C}_{40}\right)$ & $52.4 \pm 0.9 \mathrm{Aa}$ & $22.8 \pm 1.7 \mathrm{Aa}$ & $5.1 \pm 0.4 \mathrm{Aa}$ & $6.9 \pm 0.5 \mathrm{Aa}$ & $12.8 \pm 0.2 \mathrm{Aa}$ & $21.5 \pm 1.6 \mathrm{Aa}$ & $23.7 \pm 1.1 \mathrm{Ab}$ & $7.5 \pm 0.2 \mathrm{Aa}$ & $15.6 \pm 0.5 \mathrm{Aa}$ & $31.6 \pm 2.4 \mathrm{Aa}$ \\
\hline \multirow[t]{3}{*}{$144\left(\mathrm{~N}_{80}\right)$} & $0\left(\mathrm{C}_{0}\right)$ & $52.0 \pm 0.4 \mathrm{Aa}$ & $24.0 \pm 1.0 \mathrm{Aa}$ & $5.0 \pm 0.7 \mathrm{Aa}$ & $6.8 \pm 0.7 \mathrm{Aa}$ & $12.2 \pm 0.4 \mathrm{Aa}$ & $17.9 \pm 0.9 \mathrm{Ab}$ & $22.7 \pm 2.3 \mathrm{Ab}$ & $9.0 \pm 1.0 \mathrm{Aa}$ & $16.3 \pm 1.2 \mathrm{Aa}$ & $34.2 \pm 4.6 \mathrm{Aa}$ \\
\hline & $10\left(\mathrm{C}_{10}\right)$ & $54.1 \pm 0.6 \mathrm{Aa}$ & $23.8 \pm 0.4 \mathrm{Aa}$ & $6.6 \pm 1.0 \mathrm{Aa}$ & $7.0 \pm 0.1 \mathrm{Aa}$ & $8.6 \pm 1.6 \mathrm{Aa}$ & $19.6 \pm 1.7 \mathrm{Aab}$ & $29.4 \pm 1.6 \mathrm{Aa}$ & $9.2 \pm 1.2 \mathrm{Aa}$ & $17.5 \pm 1.3 \mathrm{Aa}$ & $24.3 \pm 3.1 \mathrm{Ab}$ \\
\hline & $40\left(\mathrm{C}_{40}\right)$ & $51.8 \pm 1.7 \mathrm{Aa}$ & $22.9 \pm 2.2 \mathrm{Aa}$ & $5.2 \pm 0.9 \mathrm{Aa}$ & $7.1 \pm 0.9 \mathrm{Aa}$ & $13.0 \pm 2.5 \mathrm{Aa}$ & $22.8 \pm 1.6 \mathrm{Aa}$ & $20.9 \pm 2.2 \mathrm{Ab}$ & $7.2 \pm 1.2 \mathrm{Aa}$ & $15.5 \pm 0.7 \mathrm{Aa}$ & $33.6 \pm 2.5 \mathrm{Aa}$ \\
\hline \multirow[t]{4}{*}{$108\left(\mathrm{~N}_{60}\right)$} & $0\left(\mathrm{C}_{0}\right)$ & $53.6 \pm 0.7 \mathrm{Aa}$ & $22.5 \pm 1.2 \mathrm{Aa}$ & $5.0 \pm 0.6 \mathrm{Ab}$ & $5.8 \pm 0.6 \mathrm{Aa}$ & $13.2 \pm 2.6 \mathrm{Aab}$ & $17.6 \pm 1.3 \mathrm{Ac}$ & $22.3 \pm 0.8 \mathrm{Aab}$ & $9.5 \pm 0.9 \mathrm{Aa}$ & $16.2 \pm 1.2 \mathrm{Aa}$ & $34.5 \pm 1.5 \mathrm{Aa}$ \\
\hline & $10\left(\mathrm{C}_{10}\right)$ & $55.0 \pm 1.0 \mathrm{Aa}$ & $22.7 \pm 1.9 \mathrm{Aa}$ & $7.3 \pm 0.7 \mathrm{Aa}$ & $6.1 \pm 0.9 \mathrm{Aa}$ & $8.9 \pm 1.9 \mathrm{Ab}$ & $18.2 \pm 1.5 \mathrm{Abc}$ & $26.1 \pm 1.2 \mathrm{Ba}$ & $9.8 \pm 0.8 \mathrm{Aa}$ & $16.4 \pm 2.4 \mathrm{Aa}$ & $29.5 \pm 1.8 \mathrm{Aab}$ \\
\hline & $20\left(C_{20}\right)$ & $52.2 \pm 3.3 \mathrm{Aa}$ & $21.6 \pm 1.2 \mathrm{Aa}$ & $5.3 \pm 0.5 \mathrm{Ab}$ & $6.3 \pm 0.9 \mathrm{Aa}$ & $14.6 \pm 3.3 \mathrm{Aa}$ & $21.9 \pm 1.0 \mathrm{Aab}$ & $21.4 \pm 1.7 \mathrm{Ab}$ & $8.2 \pm 0.7 \mathrm{Aa}$ & $14.8 \pm 1.0 \mathrm{Aa}$ & $33.6 \pm 3.3 \mathrm{Aa}$ \\
\hline & $40\left(\mathrm{C}_{40}\right)$ & $51.6 \pm 1.6 \mathrm{Aa}$ & $21.9 \pm 0.9 \mathrm{Aa}$ & $5.2 \pm 0.3 \mathrm{Ab}$ & $6.4 \pm 0.8 \mathrm{Aa}$ & $14.9 \pm 3.0 \mathrm{Aa}$ & $23.9 \pm 1.1 \mathrm{Aa}$ & $20.5 \pm 1.3 \mathrm{Ab}$ & $7.1 \pm 0.3 \mathrm{Aa}$ & $14.4 \pm 1.4 \mathrm{Aa}$ & $34.1 \pm 1.0 \mathrm{Aa}$ \\
\hline
\end{tabular}

Note: the letters A, B and a, b and c in a single column indicate significant difference under different nitrogen and biochar levels, respectively, using LSD test at $p<0.05$ 
Table 3. Changes in soil aggregate $(>0.25 \mathrm{~mm})$ content, mean weight diameter, geometric mean diameter and percentage of aggregate destruction with different treatments.

\begin{tabular}{|c|c|c|c|c|c|c|c|c|}
\hline \multicolumn{2}{|c|}{ Treatments } & \multirow{2}{*}{$\mathrm{DR}_{0.25}$} & \multirow{2}{*}{ D-MWD } & \multirow{2}{*}{ D-GMD } & \multirow{2}{*}{$\mathrm{WR}_{0.25}$} & \multirow{2}{*}{ W-MWD } & \multirow{2}{*}{ W-GMD } & \multirow{2}{*}{$\operatorname{PAD}_{0.25}$} \\
\hline Pure N (kg.ha $\left.{ }^{-1}\right)$ & Biochar (t.ha $\left.{ }^{-1}\right)$ & & & & & & & \\
\hline \multirow[t]{4}{*}{180} & 0 & $87.93 \pm 0.38 \mathrm{Aa}$ & $4.97 \pm 0.09 \mathrm{Aa}$ & $3.03 \pm 0.08 \mathrm{Aa}$ & $66.05 \pm 3.38 \mathrm{Ab}$ & $2.40 \pm 0.15 \mathrm{Ab}$ & $0.90 \pm 0.10 \mathrm{Ab}$ & $24.90 \pm 4.46 \mathrm{Aa}$ \\
\hline & 10 & $91.38 \pm 1.43 \mathrm{Aa}$ & $5.09 \pm 0.08 \mathrm{Aa}$ & $3.38 \pm 0.21 \mathrm{Aa}$ & $76.52 \pm 2.02 \mathrm{Aa}$ & $2.81 \pm 0.11 \mathrm{Aa}$ & $1.28 \pm 0.06 \mathrm{Aa}$ & $16.25 \pm 2.85 \mathrm{Aa}$ \\
\hline & 20 & $87.55 \pm 0.30 \mathrm{Aa}$ & $4.83 \pm 0.08 \mathrm{Aa}$ & $2.91 \pm 0.04 \mathrm{Aa}$ & $69.90 \pm 3.46 \mathrm{Aab}$ & $2.66 \pm 0.13 \mathrm{Aab}$ & $1.04 \pm 0.11 \mathrm{Ab}$ & $19.96 \pm 3.31 \mathrm{Aa}$ \\
\hline & 40 & $87.16 \pm 0.17 \mathrm{Aa}$ & $4.86 \pm 0.02 \mathrm{Aa}$ & $2.89 \pm 0.01 \mathrm{Aa}$ & $68.42 \pm 2.45 \mathrm{Ab}$ & $2.69 \pm 0.15 \mathrm{Aab}$ & $1.04 \pm 0.10 \mathrm{Ab}$ & $21.50 \pm 4.99 \mathrm{Aa}$ \\
\hline \multirow[t]{4}{*}{144} & 0 & $87.83 \pm 0.41 \mathrm{Aa}$ & $4.87 \pm 0.02 \mathrm{Aa}$ & $2.96 \pm 0.06 \mathrm{Aa}$ & $65.85 \pm 4.56 \mathrm{Ab}$ & $2.42 \pm 0.15 \mathrm{Ab}$ & $0.91 \pm 0.13 \mathrm{Ab}$ & $25.04 \pm 4.97 \mathrm{Aa}$ \\
\hline & 10 & $91.42 \pm 1.59 \mathrm{Aa}$ & $5.04 \pm 0.06 \mathrm{Aa}$ & $3.33 \pm 0.16 \mathrm{Aa}$ & $75.68 \pm 3.08 \mathrm{Aa}$ & $2.78 \pm 0.13 \mathrm{Aa}$ & $1.24 \pm 0.11 \mathrm{ABa}$ & $17.13 \pm 7.84 \mathrm{Aa}$ \\
\hline & 20 & $87.46 \pm 0.73 \mathrm{Aa}$ & $4.89 \pm 0.04 \mathrm{Aa}$ & $2.92 \pm 0.09 \mathrm{Aa}$ & $69.63 \pm 4.07 \mathrm{Aab}$ & $2.70 \pm 0.18 \mathrm{Aab}$ & $1.06 \pm 0.13 \mathrm{Aab}$ & $20.35 \pm 6.69 \mathrm{Aa}$ \\
\hline & 40 & $87.01 \pm 2.52 \mathrm{Aa}$ & $4.83 \pm 0.09 \mathrm{Aa}$ & $2.86 \pm 0.20 \mathrm{Aa}$ & $66.36 \pm 2.52 \mathrm{Ab}$ & $2.69 \pm 0.15 \mathrm{Aab}$ & $0.98 \pm 0.09 \mathrm{Ab}$ & $23.70 \pm 2.29 \mathrm{Aa}$ \\
\hline \multirow[t]{4}{*}{108} & 0 & $86.85 \pm 2.56 \mathrm{Aab}$ & $4.93 \pm 0.08 \mathrm{Aab}$ & $2.95 \pm 0.21 \mathrm{Aab}$ & $65.52 \pm 1.49 \mathrm{Aa}$ & $2.39 \pm 0.06 \mathrm{Ab}$ & $0.89 \pm 0.02 \mathrm{Aa}$ & $24.45 \pm 5.95 \mathrm{Aa}$ \\
\hline & 10 & $91.11 \pm 1.92 \mathrm{Aa}$ & $5.08 \pm 0.01 \mathrm{Aa}$ & $3.35 \pm 0.13 \mathrm{Aa}$ & $70.47 \pm 1.75 \mathrm{Aa}$ & $2.57 \pm 0.09 \mathrm{Aab}$ & $1.04 \pm 0.05 \mathrm{Ba}$ & $22.63 \pm 2.37 \mathrm{Aa}$ \\
\hline & 20 & $85.38 \pm 3.28 \mathrm{Ab}$ & $4.81 \pm 0.23 \mathrm{Aab}$ & $2.76 \pm 0.33 \mathrm{Ab}$ & $66.37 \pm 3.29 \mathrm{Aa}$ & $2.65 \pm 0.09 \mathrm{Aab}$ & $0.98 \pm 0.09 \mathrm{Aa}$ & $22.22 \pm 3.82 \mathrm{Aa}$ \\
\hline & 40 & $85.11 \pm 3.01 \mathrm{Ab}$ & $4.77 \pm 0.16 \mathrm{Ab}$ & $2.71 \pm 0.29 \mathrm{Ab}$ & $65.93 \pm 0.97 \mathrm{Aa}$ & $2.75 \pm 0.05 \mathrm{Aa}$ & $0.99 \pm 0.02 \mathrm{Aa}$ & $22.47 \pm 2.77 \mathrm{Aa}$ \\
\hline
\end{tabular}

Note: the letters A, B and a and b in a single column indicate significant difference under different nitrogen and biochar levels, respectively, using LSD test at $p<0.05$. WR 0.25 means content of $>0.25 \mathrm{~mm}$ soil water-stable aggregates; $\mathrm{DR}_{0.25}$ means content of $>0.25 \mathrm{~mm}$ soil mechanical-stable aggregates; W-MWD means mean weight diameter of water-stable aggregates; D-MWD means mean weight diameter of mechanical-stable aggregates; W-GMD means geometric mean diameter of water-stable aggregates; D-GMD means geometric mean diameter of mechanical-stable aggregates; $\mathrm{PAD}_{0.25}$ means $>0.25 \mathrm{~mm}$ percentage of aggregate destruction. 
After the application of biochar, $\mathrm{PAD}_{0.25}$ for the each nitrogen fertilizer slightly decreased. The $\mathrm{PAD}_{0.25}$ of $\mathrm{C}_{10}$ for the each nitrogen fertilizer treatment was the lowest basically which decreased by $7.44 \%-34.74 \%$ as compared to $C_{0}$, but there was no significant difference $(p>0.05)$ (Table 3$)$. In general, biochar could enhance the water-stability of soil aggregates for the each nitrogen fertilizer, while the application of $10 \mathrm{t}^{\mathrm{h}} \mathrm{ha}^{-1}$ biochar served this purpose better. In addition, the combined application of $\mathrm{C}_{10}$ and $\mathrm{N}_{100}$ or $\mathrm{N}_{80}$ had a better improving effect on soil water-stable aggregates, compared with $\mathrm{N}_{60}$.

\subsection{Effect of Biochar and Nitrogen Fertilizer on Total Organic Carbon in Soil Mechanical-Stable Aggregates}

As shown in Figure 1, TOC content in macro-aggregates $(>0.25 \mathrm{~mm})$ of soil mechanical-stable aggregates were basically all increased after biochar incorporation into soil for each nitrogen fertilizer treatment, and had an increasing trend with biochar increase. For $\mathrm{N}_{100}$ treatment, only the TOC content of $C_{40}$ in the $0.25-1 \mathrm{~mm}$ aggregates was significant higher than that of $C_{0}$ and the increases was $35.00 \%(p<0.05)$. Nevertheless, for $\mathrm{N}_{80}$ and $\mathrm{N}_{60}$ treatments, $\mathrm{C}_{20}$ and $\mathrm{C}_{40}$ all caused a significant increase in TOC content in $0.25-1 \mathrm{~mm}$ and $1-2 \mathrm{~mm}$ aggregates $(p<0.05)$, compared with $\mathrm{C}_{0}$ (except for $\mathrm{N}_{80} \mathrm{C}_{20}$ treatment in the 1-2 mm aggregate). In the 0.25-1 mm aggregates, the TOC content were $11.05 \mathrm{~g} \cdot \mathrm{kg}^{-1}\left(\mathrm{~N}_{80} \mathrm{C}_{20}\right), 11.66 \mathrm{~g} \cdot \mathrm{kg}^{-1}\left(\mathrm{~N}_{80} \mathrm{C}_{40}\right), 12.78 \mathrm{~g} \cdot \mathrm{kg}^{-1}\left(\mathrm{~N}_{60} \mathrm{C}_{20}\right)$ and $13.69 \mathrm{~g} \cdot \mathrm{kg}^{-1}\left(\mathrm{~N}_{60} \mathrm{C}_{40}\right)$ after the application of biochar, and the increase rates were $21.00 \%, 28.00 \%, 36.00 \%$ and $46.00 \%$, under $\mathrm{N}_{80} \mathrm{C}_{20}$, $\mathrm{N}_{80} \mathrm{C}_{40}, \mathrm{~N}_{60} \mathrm{C}_{20}$ and $\mathrm{N}_{60} \mathrm{C}_{40}$, respectively, compared with the treatments of $\mathrm{C}_{0}$ combined with same nitrogen fertilizer application rate. Similarly, in the 1-2 $\mathrm{mm}$ aggregates, the biochar increased the TOC content by $15.00 \%\left(\mathrm{~N}_{80} \mathrm{C}_{20}\right), 25.00 \%\left(\mathrm{~N}_{80} \mathrm{C}_{40}\right), 27.00 \%\left(\mathrm{~N}_{60} \mathrm{C}_{20}\right)$ and $44.00 \%\left(\mathrm{~N}_{60} \mathrm{C}_{40}\right)$. In the $<0.25 \mathrm{~mm}$ aggregates, the application of biochar also increased the TOC content. This indicated that the application of biochar for each nitrogen fertilizer treatment could increase the TOC content of soil mechanical-stable aggregates. In particular the increases of TOC content in the $<2 \mathrm{~mm}$ aggregates were more remarkable and the effect of higher application of biochar $\left(20 \mathrm{t} \cdot \mathrm{ha}^{-1}\right.$ or $\left.40 \mathrm{t} \cdot \mathrm{ha} \mathrm{a}^{-1}\right)$ on increasing the TOC content was better.

\subsection{Effect of Biochar and Nitrogen Fertilizer on Rapeseed Yield}

Figure 2 shows that biochar and nitrogen fertilizer significantly affected rapeseed yield in 2018 and $2019(p<0.01)$. Compared with no biochar, biochar increased rapeseed yield for $\mathrm{N}_{100}$ and $\mathrm{N}_{80}$ treatments, while only $\mathrm{N}_{80} \mathrm{C}_{10}$ treatment significantly increased $(p<0.05)$ rapeseed yield in the first year after biochar was applied (2018), being increased by $18.03 \%$ as compared to $\mathrm{N}_{80} \mathrm{C}_{0}$. Two years later (2019), compared with $\mathrm{N}_{100} \mathrm{C}_{0}, \mathrm{~N}_{100} \mathrm{C}_{10}, \mathrm{~N}_{100} \mathrm{C}_{20}$ and $\mathrm{N}_{100} \mathrm{C}_{40}$ significantly increased $(p<0.05)$ rapeseed yields by $33.99 \%, 27.09 \%$ and $26.60 \%$ respectively. For $\mathrm{N}_{60}$ and $\mathrm{N}_{80}$ treatment, only $\mathrm{C}_{10}$ significantly increased rapeseed yield $(p<0.05)$ by $22.08 \%$ and $45.65 \%$, respectively, as compared to $C_{0}$. However, rapeseed yield was slightly decreased after the application of high biochar rate $\left(C_{20}\right.$ and $\left.C_{40}\right)$ in the $\mathrm{N}_{60}$ treatment, and $\mathrm{C}_{40}$ significant decreased $(p<0.05)$ rapeseed yield in 2019. These results showed that compared with $\mathrm{N}_{60}$, the combination of biochar with $\mathrm{N}_{80}$ and $\mathrm{N}_{100}$ was more conducive to the increase of rapeseed yield, especially at the optimal dosage of $10 \mathrm{t} \cdot \mathrm{ha}^{-1}$.

For the same biochar application, the reduction of nitrogen fertilizer $\left(\mathrm{N}_{80}\right.$ and $\left.\mathrm{N}_{60}\right)$ reduced the two-year rapeseed yield by $11.67 \%$ and $31.67 \%$, respectively, compared with that of $\mathrm{N}_{100}$. Interactive effects of biochar and nitrogen fertilizer were also highly significant in $2019(p<0.01)$, and the highest yield of rapeseed was obtained by the combination of $10 \mathrm{t} \cdot \mathrm{ha}^{-1}$ biochar and $180 \mathrm{~kg} \cdot \mathrm{ha}^{-1}$ pure nitrogen in two consecutive years, which had no statistical difference with $\mathrm{N}_{80} \mathrm{C}_{10}(p>0.05)$. However, the two-year yields of the $\mathrm{N}_{80} \mathrm{C}_{10}$ treatment were all higher than those of $\mathrm{N}_{100} \mathrm{C}_{0}$, and the difference of yield between them reached a significant level in $2019(p<0.05)$. Compared with $\mathrm{N}_{100} \mathrm{C}_{0}$, the two-year average yield of $\mathrm{N}_{80} \mathrm{C}_{10}$ was increased by $16.11 \%$. This indicated that the application of $10 \mathrm{t} \cdot \mathrm{ha}^{-1}$ biochar could replace $20 \%$ pure nitrogen to still achieve high yield as compared to conventional nitrogen application. 

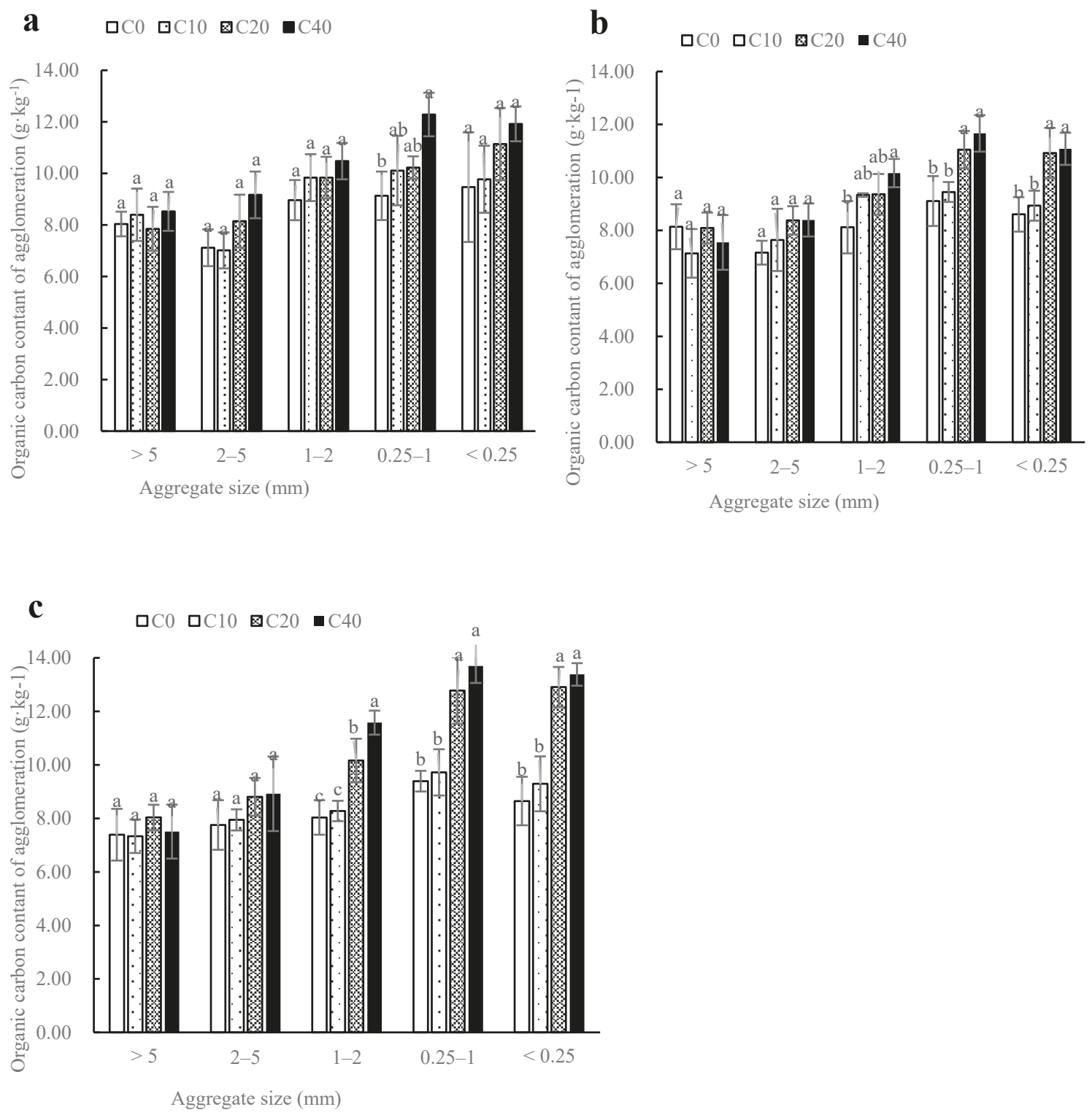

Figure 1. The content and distribution of organic carbon in mechanical-stable aggregates in the soil with biochar combined with conventional nitrogen application (a), 80\% of conventional nitrogen application (b) and $60 \%$ of conventional nitrogen application (c). Different lowercase letters indicate significant differences among biochar treatments at the same nitrogen fertilizer at $\operatorname{LSD}_{0.05}$. 

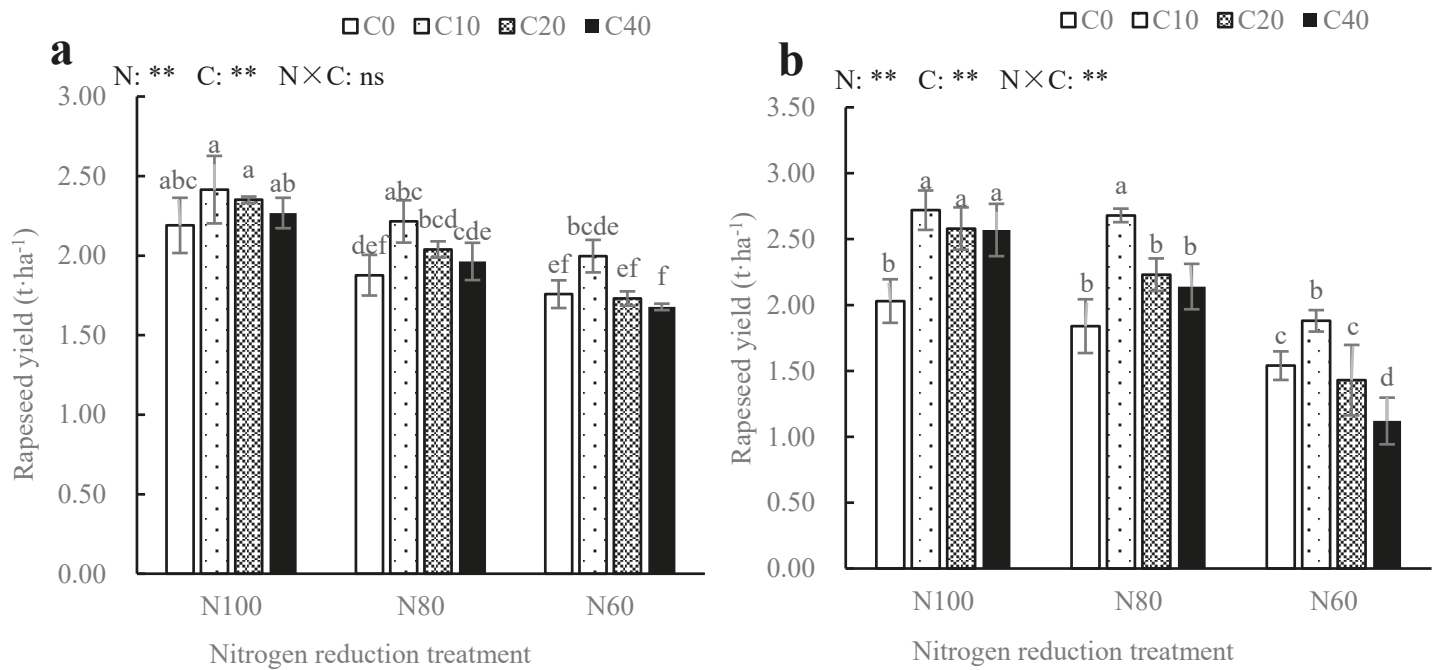

Figure 2. Rapeseed yield of biochar combined with reducing nitrogen application rate in 2018 (a) and 2019 (b). Different lowercase letters indicate significant differences at the different treatments at $\operatorname{LSD}_{0.05}$. $\mathrm{N}$ means nitrogen fertilizer; $\mathrm{C}$ means biochar; the " $\mathrm{ns}$ " means the difference is not significant and the “***" indicate significant difference at $p<0.01$.

\subsection{Correlation of Soil Aggregate Stability with Rapeseed Yield}

In the present study, the regression analysis was performed to examine the relationships between indicators of soil structure stability $\left(\mathrm{DR}_{0.25}, \mathrm{WR}_{0.25}, \mathrm{PAD}_{0.25}\right.$, D-MWD, D-GMD, W-MWD and W-GMD) and rapeseed yield in 2019 (Figure 3 ). $\mathrm{DR}_{0.25}, \mathrm{WR}_{0.25}$ and $\mathrm{W}-\mathrm{GMD}$ had the strongest positive associations with rapeseed yield $(p<0.01)$, with the $r$ values of $0.454,0.598$ and 0.569 , respectively. D-MWD, D-GMD and W-MWD were also significantly related with rapeseed yield $(p<0.05)$, with correlation coefficients of $0.332,0.340$ and 0.414 , respectively, whereas $\mathrm{PAD}_{0.25}$ had a significant negative correlation with rapeseed yield $(p<0.05 ; \mathrm{r}=-0.414)$.
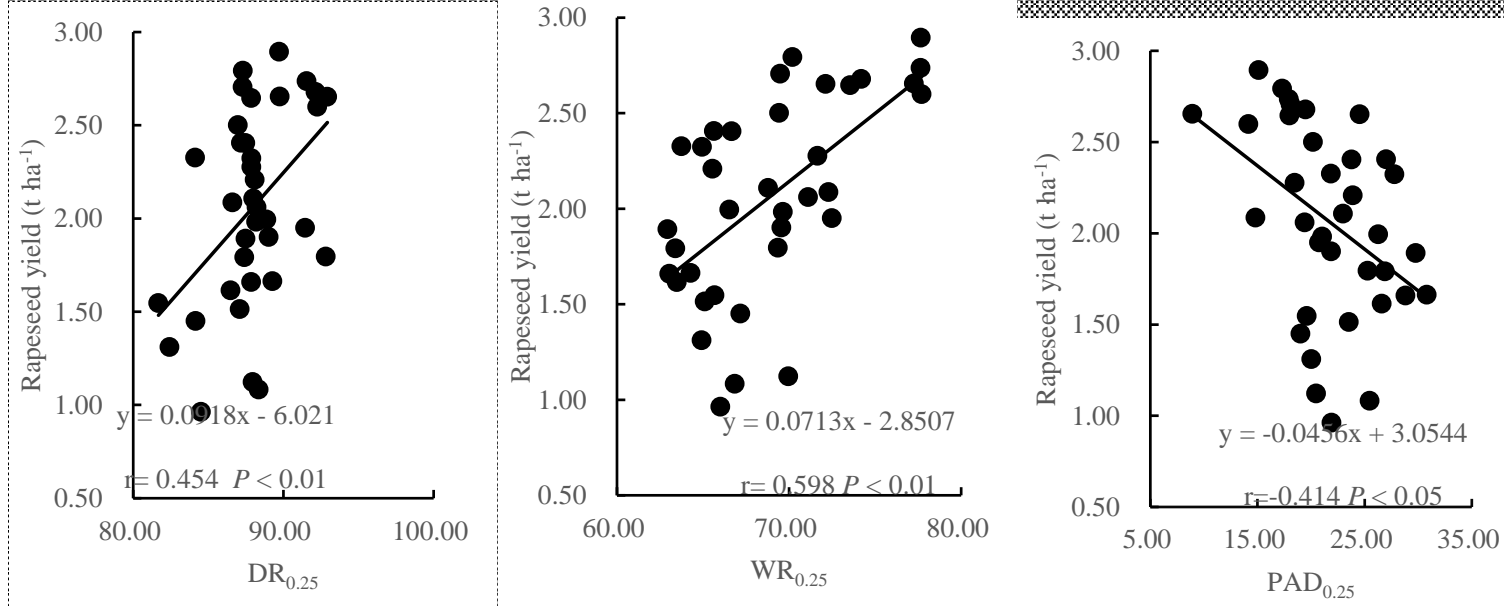

Figure 3. Cont. 

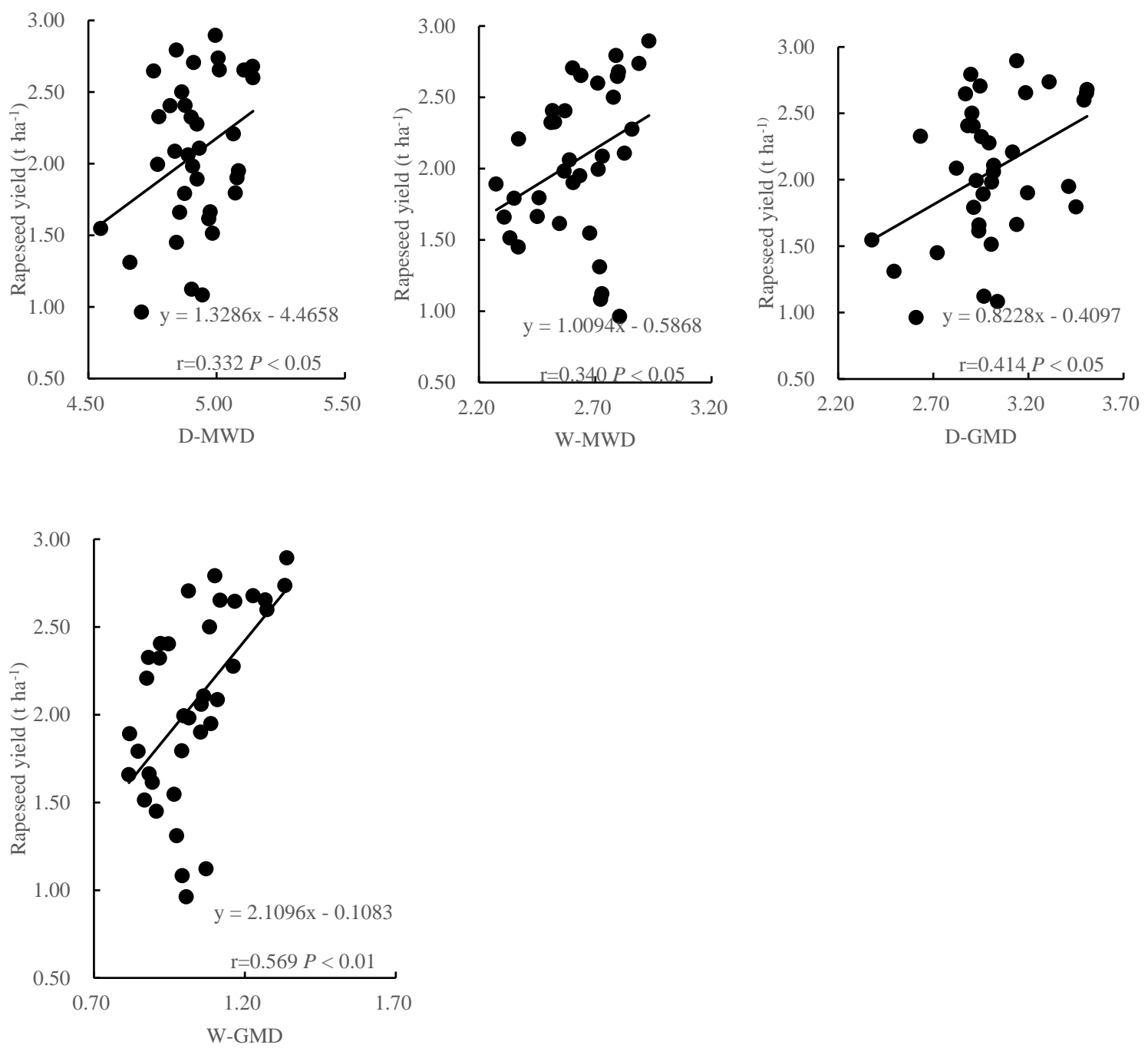

Figure 3. Relationship between soil aggregate index and rapeseed yield $\mathrm{WR}_{0.25}$ means content of $>0.25 \mathrm{~mm}$ soil water-stable aggregates; $\mathrm{DR}_{0.25}$ means content of $>0.25 \mathrm{~mm}$ soil mechanical-stable aggregates; W-MWD means mean weight diameter of water-stable aggregates; D-MWD means mean weight diameter of mechanical-stable aggregates; W-GMD means geometric mean diameter of water-stable aggregates; D-GMD means geometric mean diameter of mechanical-stable aggregates and $\mathrm{PAD}_{0.25}$ means $>0.25 \mathrm{~mm}$ percentage of aggregate destruction.

\subsection{The Relationship between Rapeseed Yield and Application Rates of Biochar-Nitrogen Fertilizer}

To study the relationship between rapeseed yield and application rates of biochar and nitrogen fertilizer, the multidimensional nonlinear regression model was built, in which biochar and nitrogen fertilizer were defined as independent variables and rapeseed yield was defined as dependent variable. The multidimensional nonlinear regression model was shown below:

$$
z=-0.6741+30.3611 x-0.0027 y+0.1983 x y-81.3401 x^{2}-0.0007 y^{2}\left(R^{2}=0.831\right) .
$$

In this equation, $x$ is the nitrogen fertilizer application rate $\left(\mathrm{t} \cdot \mathrm{ha}^{-1}\right) ; y$ is biochar application rate $\left(\mathrm{t} \cdot \mathrm{ha}^{-1}\right) ; x y$ is the interactive effects of biochar and nitrogen fertilizer and $z$ is the rapeseed yield $\left(\mathrm{t} \cdot \mathrm{ha}^{-1}\right)$. Based on the equation, the 3D color map surface was built. As shown in Figure 4, the combined application of biochar and nitrogen fertilizer could increase rapeseed yield, while the increased rate of rapeseed yield tended to be gradual with biochar and nitrogen fertilizer increasing, and excessive application of biochar and nitrogen fertilizer even decreased the rapeseed yield. From the multidimensional regression model, it could be seen that the partial regression coefficient of nitrogen 
application rate (30.3611), which could reflect the contribution of nitrogen fertilizer to rapeseed yield, was greater than that of biochar application rate (0.0027). This indicated that the effect of biochar on rapeseed yield was smaller than that of nitrogen fertilizer. Moreover, the partial regression coefficient of nitrogen fertilizer and biochar combined with nitrogen fertilizer were greater than zero, indicating that nitrogen fertilizer and biochar combined with nitrogen fertilizer had positive effect on rapeseed yield. On the contrary, biochar had a slight inhibitory effect on rapeseed yield, indicating that a certain amount of nitrogen fertilizer could be combined to increase rapeseed yield. By computing the multi-dimensional regression models, the highest yield of rapeseed would be $2.67 \mathrm{t} \cdot \mathrm{ha}^{-1}$, which could be achieved with a combined application of biochar and nitrogen fertilizer of $30 \mathrm{t} \cdot \mathrm{ha}^{-1}$ and $223 \mathrm{~kg} \cdot \mathrm{ha}^{-1}$, respectively. By comparison with the highest yield, $\mathrm{N}_{80} \mathrm{C}_{10}$ (with yield of $2.45 \mathrm{t} \cdot \mathrm{ha}^{-1}$ ) would reduce $35.43 \%$ nitrogen fertilizer in the case of small yield difference. It showed that the application of $10 \mathrm{t} \cdot \mathrm{ha}^{-1}$ biochar could replace $35.43 \%$ pure nitrogen to achieve stable production compared the management combination with the highest yield.

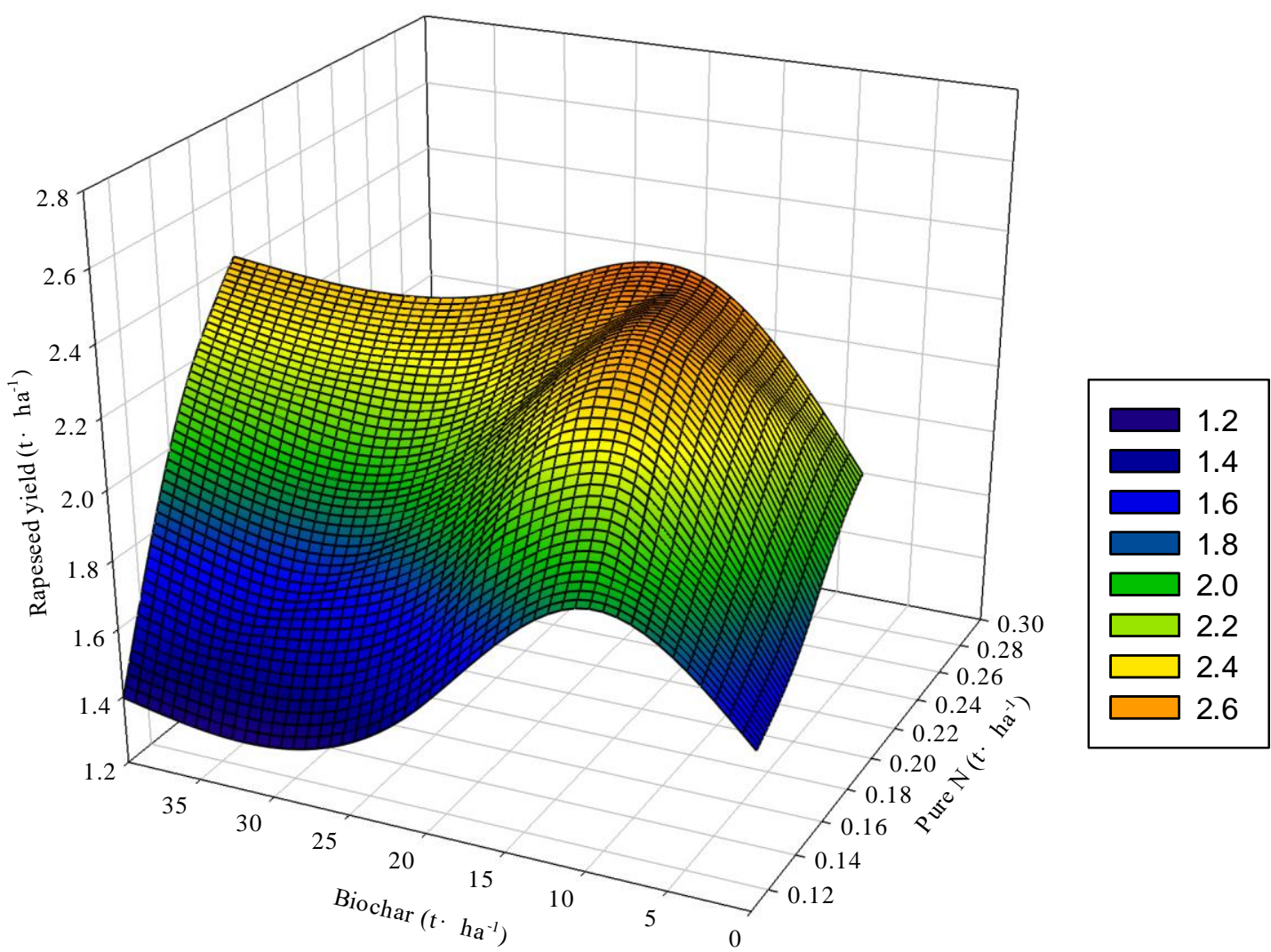

Figure 4. The relationship between rapeseed yield and application rates of biochar and $\mathrm{N}$ fertilizer in a 3D color map surface image.

\section{Discussion}

\subsection{Effect of Biochar and Nitrogen Fertilizer on Content and Distribution of Soil Aggregates}

Soil aggregates are the basic units of soil structure as well as the material basis of soil fertility, whose content and distribution are considered to be an important indicator of good soil aggregate structure, and play an important role in maintaining soil productivity. Organic fertilizer combined with inorganic fertilizer [19], straw returning or adding biochar [6] and conservation tillage [20] all increased the proportion of soil macroaggregates $(>0.25 \mathrm{~mm})$ and consequently increased soil aggregate stability. In this study, compared with no biochar, biochar increased content of soil mechanical-stable aggregates in 1-2 $\mathrm{mm}$ size and soil water-stable aggregates in $>5 \mathrm{~mm}$ size for each nitrogen fertilizer. 
Besides, application of $10 \mathrm{t} \cdot \mathrm{ha}^{-1}$ biochar overall significantly increased the soil water-stable aggregates in 2-5 mm size for each nitrogen fertilizer with an increase rate of $17.04 \%-33.04 \%$, because of a corresponding decline in the percentage of micro-aggregates $(<0.25 \mathrm{~mm})$. This agreed with study results of Liu et al. [19], who found that the soil water stable aggregate $(>0.25 \mathrm{~mm})$ in the $0-15 \mathrm{~cm}$ soil layer had a remarkable increase after biochar application of $40 \mathrm{t} \cdot \mathrm{ha} \mathrm{a}^{-1}$. This may be because biochar can adsorb and fix a variety of inorganic ions and polar or non-polar organic compounds, and then form organic-inorganic composites and large-size aggregates in soil due to its porous structure and large specific surface area [21]. In addition, biochar can produce organic matter such as polysaccharides and proteins by decomposition, and also produces more secretions due to increase of microbial activity in soil, thereby promotes the formation of soil large aggregates [22]. However, Dong et al. [6] found that the degree of soil aggregation in sandy loam had no significant change after three years of biochar application, possibly because of the difference in soil types. Compared with silty soil, sandy soil has poor adsorption capacity for soil organic carbon, and it is difficult to form a stable organic-inorganic composite with macromolecular organic matter [11], thus causing different response of soil aggregation to biochar.

However, in this study, higher biochar application $\left(20 \mathrm{or} 40 \mathrm{t} \cdot \mathrm{ha} \mathrm{a}^{-1}\right)$ was found to have no significant effect on the content of soil large aggregates. This might be because biochar could increase the soil total porosity and the soil water conservation capacity, and the soil total porosity was increased with the increase of biochar application rate [11]. The sampling time in this study was during the ripening stage of rapeseed, immediately after the end of the rainy season, and the soil in surface layer $(0-20 \mathrm{~cm})$ was greatly affected by rainfall, which increased the water content of surface soil, and thus decreased the soil cohesive force causing soil to be easily dispersed. In addition, biochar produced by high temperature with highly carboxylated and stable aromatization structure is mainly composed of inert carbon, which is difficult to be decomposed and utilized by microorganisms, and may not produce mucus aggregate particles [23]. Furthermore, biochar reduces the activity of enzymes related to organic carbon turnover due to adsorption of soil enzymes by biochar [24]. Therefore, under our experimental conditions, the effect of higher biochar application on formation of soil large aggregates was not significant.

\subsection{Effect of Biochar and Nitrogen Fertilizer on Soil Stability Index}

$\mathrm{R}_{0.25}$, MWD and GMD are common indicators to reflect the size distribution of soil aggregates. Greater $\mathrm{R}_{0.25}$, MWD and GMD indicate higher stability of soil aggregate structure [25]. In this study, biochar amendment at $10 \mathrm{t} \cdot \mathrm{ha}^{-1}$ significantly increased $\mathrm{WR}_{0.25}$, W-MWD and W-GMD under the treatments of conventional pure nitrogen application and $80 \%$ of conventional pure nitrogen application treatments as well as decreased the destruction of macroaggregates, which suggested that the positive effect of biochar combined with nitrogen fertilizer on increasing aggregate stability and improving soil structure in the purple soil. It can be seen from Table 1 that $10 \mathrm{t} \cdot \mathrm{ha}^{-1}$ biochar significantly promoted the formation of soil water-stable aggregates in $2-5 \mathrm{~mm}$ size range under conventional nitrogen application and $80 \%$ of conventional nitrogen application, thereby significantly increased soil aggregate stability. However, Busscher et al. [26] found no significant change in aggregate content after 70 days of different amounts of biochar application. The main reason for these differences may be related to the differences in soil texture and soil organic matter content. In addition, the formation of soil aggregates requires an appropriate duration of time, and many studies are based on short-term tests, which may be another reason for the different test results. Therefore, the effect of biochar on the stability of soil aggregates requires more in-depth research.

However, $10 \mathrm{t} \cdot \mathrm{ha}^{-1}$ biochar had no significant effect on soil $\mathrm{WR}_{0.25}$, W-MWD and W-GWD under the treatment of $60 \%$ of conventional nitrogen application, because there was no significant increase in content of soil water-stable aggregates in 2-5 mm size range after adding $10 \mathrm{t} \cdot \mathrm{ha}^{-1}$ biochar, which might be related to the reduction in content of soil water-stable aggregates in $2-5 \mathrm{~mm}$ size range resulted from nitrogen reduction (Table 2). Li et al. [15] found that biochar and nitrogen fertilizer had significant 
interaction effects on the stability of soil aggregates. Compared with conventional fertilization, no biochar and the $1 \mathrm{t} \cdot \mathrm{ha}^{-1}$ biochar application under the treatment of nitrogen fertilizer reduction significantly reduced water-stable aggregates, but there was no significant difference between the 5 and $10 \mathrm{t} \cdot \mathrm{ha}^{-1}$ biochar application. This suggests that the application of higher biochar may be more conducive to the stability of water-stable aggregates when soil fertility is low or conventional nitrogen fertilizer is reduced.

\subsection{Effect of Biochar and Nitrogen Fertilizer on Total Organic Carbon in Soil Mechanical-Stable Aggregates}

SOM, as an important aggregate binding agent, plays an important role in the formation of large aggregates and the improvement of soil structure [27]. This study demonstrated that biochar amendment led to an increase in soil organic carbon in 2-5, 1-2, 0.25-1 and $<0.25 \mathrm{~mm}$ aggregates for each nitrogen fertilizer treatment, and SOC in $2-5,1-2,0.25-1$ and $<0.25 \mathrm{~mm}$ aggregates increased with the increase in biochar application. This was because the organic carbon content of biochar used in this experiment was $537.97 \mathrm{~g} \cdot \mathrm{kg}^{-1}$, being a carbon-rich exogenous organic matter, thus it could increase the soil microbial biomass and promote the formation of soil humus to contribute to the formation of organic macromolecules such as carbohydrates and aromatic hydrocarbons, thereby increasing the content of soil organic carbon and producing more cementing materials, finally resulting in the redistribution of microaggregates in the soil into large aggregates [28]. This was also the reason why the application of $10 \mathrm{t} \cdot \mathrm{ha}^{-1}$ biochar in this study promoted the formation of soil large aggregates and thus improved the stability of soil aggregates.

By analyzing the organic carbon content of aggregates in each size range, we could clearly understand the outward distribution of exogenous new carbon in soil aggregates and its influence on soil aggregate stability, which may help to reveal the sequestration and protection mechanism of soil organic carbon. Gao et al. [29] showed that the organic carbon content of soil aggregates increased as the aggregate fraction size increased, and large aggregates could absorb more carbon. However, in our study, soil organic carbon was mainly stored in soil aggregates of $0.25-1$ and $<0.25 \mathrm{~mm}$ size ranges, and high level of biochar ( 20 or $40 \mathrm{t} \cdot \mathrm{ha}^{-1}$ ) significantly increased the total organic carbon of these two fractions for each nitrogen treatment. This might be because in this experiment, conventional tillage was frequently carried out by mechanical tillage and caused breakage of soil large aggregates ( $>5$ and $2-5 \mathrm{~mm}$ ), thus they became easily attacked by microorganism, resulting in accelerating mineralization of SOM, and the retention of SOM was unfavorable [30]. However, through the action of stabilizing force, biochar combined with soil minerals to form aggregates, whose physical protection could reduce the decomposition of soil organic carbon in aggregates of $1-2,0.25-1$ and $<0.25 \mathrm{~mm}$ size ranges by microorganism. At the same time, colloidal components with high degree of humification such as humic acid and fulvic acid became relatively enriched in micro-aggregates, and new carbon with high degree of humification or aromatic carbon, which was difficult to be utilized by microorganisms was stably stored by wrapping effect of powdery minerals [31].

\subsection{Effect of Biochar and Nitrogen Fertilizer on Rapeseed Yield}

Soil aggregate structure is not only an important factor in plant growth and water transport in soil, but also plays an important role in soil physical and chemical properties and biological processes [32]. Early studies have shown that more stable soil aggregate structure indicates stronger soil ability to resist erosion, and higher soil fertility and crop yield [27]. Our experiment could also prove this result since the stability of soil aggregates was significantly correlated with rapeseed yield (Figure 3). The larger the values of $R_{0.25}$, MWD and GMD were, the smaller the aggregate destruction rate was and the higher the rapeseed yield was. In our experiment, biochar with application rate of $10 \mathrm{t} \cdot \mathrm{ha}^{-1}$ for 2 years under different nitrogen fertilizer treatments significantly increased rapeseed yields by $22.08 \%-45.65 \%$ as compared to no biochar treatments. This was because some indicators as evaluating soil quality $\left(\mathrm{R}_{0.25}\right.$, MWD, GMD and $\mathrm{PAD}_{0.25}$ ) were improved after the biochar application, which reflected that biochar combined with nitrogen fertilizer significantly improved the stability of soil aggregates. This indicated 
that stable soil aggregates could provide a good soil environment for crop growth, thus increasing the nutrient utilization and yield of crops. Yuan et al. [16] also showed that the combined application of biochar and nitrogen fertilizer improved the stability of soil aggregates, and the physical and chemical properties of soil and micro-ecological environment also had obvious improvement, which provided favorable growth conditions for jujube, and thus increasing the jujube yield.

This study also found that the interaction effect of biochar and nitrogen fertilizer on rapeseed yield was positively significant (Figures 2 and 4). In all treatments, rapeseed yield of the $\mathrm{N}_{100} \mathrm{C}_{10}$ treatment was the highest, which had no significant difference with that of the $\mathrm{N}_{80} \mathrm{C}_{10}$ treatment in 2 years. However, rapeseed yield of $\mathrm{N}_{80} \mathrm{C}_{10}$ treatment was significantly higher than that of conventional fertilization treatment, with the average yield in 2 years increased by $16.11 \%$. This indicated that compared with the conventional fertilization, $10 \mathrm{t}^{\mathrm{h}} \mathrm{ha}^{-1}$ biochar could replace $20 \%$ of nitrogen fertilizer to achieve high yield, which have been proven by many researchers [33]. At the same time, the combined application of $30 \mathrm{t} \cdot \mathrm{ha}^{-1}$ biochar and $223 \mathrm{~kg} \cdot \mathrm{ha}^{-1}$ nitrogen fertilizer could achieve the highest rapeseed yield $\left(2.67 \mathrm{t}^{-\mathrm{ha}^{-1}}\right)$ by the analysis of multivariate nonlinear regression equations, which was only $8.98 \%$ higher than rapeseed yield of the $\mathrm{N}_{80} \mathrm{C}_{10}$ treatment, but the $\mathrm{N}_{80} \mathrm{C}_{10}$ treatment could reduce $35.43 \%$ nitrogen fertilizer. Based on the results of this experiment, $10 \mathrm{t} \cdot \mathrm{ha}^{-1}$ biochar combined with $144 \mathrm{~kg} \cdot \mathrm{ha}^{-1}$ pure nitrogen ( $80 \%$ of conventional nitrogen) is conducive not only to enhance the stability of soil aggregates in purple soil and increase the fixation of organic carbon, but also to improve rapeseed yield greatly under the condition of $20 \%$ reduction of nitrogen fertilizer. This study will not only improve the capacity of fixed carbon and reducing discharge in farmland and achieve the coordination of agricultural production and ecological functions, but also greatly decrease water and soil pollution from nitrogen fertilize.

This study mainly focused on the study of the physical and chemical properties of soil aggregates under different application rates of biochar and nitrogen fertilizer. It is necessary to further study soil biological properties, so as to better reveal the variation mechanism of aggregate composition and organic carbon distribution in purple soil, which could provide a scientific basis for the rational application of biochar in agricultural production.

\section{Conclusions}

Biochar $\left(10 \mathrm{t} \cdot \mathrm{ha}^{-1}\right)$ significantly increased soil water-stable aggregates of $2-5 \mathrm{~mm}$ size, $\mathrm{WR}_{0.25}$, W-MWD and W-GMD for conventional nitrogen application and $80 \%$ of conventional nitrogen application treatments, but reduced the breakage of soil macro-aggregates and consequently increased soil aggregate stability. Moreover, biochar also significantly increased the TOC in soil mechanical-stable aggregates under each nitrogen fertilizer treatment, especially the TOC in soil aggregates of 1-2, $0.25-1$ and $<0.25 \mathrm{~mm}$ size ranges. Reducing nitrogen application rate decreased rapeseed yield, while applying $10 \mathrm{t} \cdot \mathrm{ha}^{-1}$ biochar into soil, rapeseed yield for each nitrogen fertilizer treatment was significantly increased and $20 \%$ of nitrogen fertilizer could be replaced when compared with conventional nitrogen application. Compared with the combination of biochar and nitrogen fertilizer under which the highest yield ( $\left.2.67 \mathrm{t} \cdot \mathrm{ha}^{-1}\right)$ could be achieved according to the analysis of multidimensional regression model, the application of $10 \mathrm{t} \cdot \mathrm{ha}^{-1}$ biochar combined with $80 \%$ of conventional nitrogen fertilizer could save $35.43 \%$ of nitrogen fertilizer input, while the yield only decreased by $8.24 \%$. The present study suggested a great potential of applying $10 \mathrm{t}^{\mathrm{h}} \mathrm{ha}^{-1}$ biochar combined with $144 \mathrm{~kg} \cdot \mathrm{ha} \mathrm{a}^{-1}$ pure nitrogen to achieve favorable soil structure with sustaining rapeseed productivity in upland purple soils in southwest China.

Author Contributions: X.T. and L.W. conceived and designed the experiments; X.T., Z.L., B.L. (Biao Li), M.D., B.L. (Bangyan Liu) and Y.W. performed the experiments; X.T. analyzed the data and wrote the paper. All authors have read and agreed to the published version of the manuscript.

Funding: This research was supported by the Public Welfare Industry (Agriculture) Research Project (201503127), National Natural Science Foundation (31271673, 31700364, 31871583), and Central University Basic Scientific Research Operating Expenses Special (XDJK2019D024). 
Conflicts of Interest: The authors declare no conflict of interest.

\section{References}

1. Shen, C.Y.; Wang, Y.; Zhao, L.P.; Xu, X.H.; Yang, X.K.; Liu, X.L. Characteristics of material migration during soil erosion in sloped farmland in the black soil region of Northeast China. Trop. Conserv. Sci. 2019, 12, 1-11. [CrossRef]

2. Ramos, M.C.; Pareja-Sánchez, E.; Plaza-Bonilla, D.; Cantero-Martínez, C.; Lampurlanés, J. Soil sealing and soil water content under no-tillage and conventional tillage in irrigated corn: Effects on grain yield. Hydrol. Process. 2019, 33, 2095-2109. [CrossRef]

3. Yan, L.; Jiang, X.X.; Ji, X.N.; Zhou, L.T.; Li, S.Y.; Chen, C.; Li, P.Y.; Zhu, Y.C.; Dong, T.H.; Meng, Q.F. Distribution of water-stable aggregates under soil tillage practices in a black soil hillslope cropland in Northeast China. J. Soils Sediments 2019. [CrossRef]

4. Nouri, A.; Lee, J.; Yin, X.H.; Saxton, A.M.; Tyler, D.D.; Sykes, V.R.; Arelli, P. Crop species in no-tillage summer crop rotations affect soil quality and yield in an Alfisol. Geoderma 2019, 345, 51-62. [CrossRef]

5. Tian, X.M.; Fan, H.; Wang, J.Q.; Ippolito, J.; Li, Y.B.; Feng, S.S.; An, M.J.; Zhang, F.H.; Wang, K.Y. Effect of polymer materials on soil structure and organic carbon under drip irrigation. Geoderma 2019, 340, $94-103$. [CrossRef]

6. Liu, M.; Han, G.L.; Zhang, Q. Effects of soil aggregate stability on soil organic carbon and nitrogen under land use change in an erodible region in Southwest China. Int. J. Environ. Res. Public Health 2019, 16, 3809. [CrossRef]

7. Li, X.P.; Shi, X.J. Effect of long-term imbalance fertilization on purple soil fertility. J. Plant Nutr. Fertil. 2007, 13, 27-32.

8. Yang, S.H.; Jiang, Z.W.; Sun, X.; Ding, J.; Xu, J.Z. Effects of biochar amendment on $\mathrm{CO}_{2}$ emissions from paddy fields under water-saving irrigation. Int. J. Environ. Res. Public Health 2018, 15, 2580. [CrossRef]

9. Xing, Y.; Wang, J.X.; Shaheen, S.M.; Feng, X.B.; Chen, Z.; Zhang, H.; Rinklebe, J. Mitigation of mercury accumulation in rice using rice hull-derived biochar as soil amendment: A field investigation. J. Hazard. Mater. 2019, 121747. [CrossRef]

10. Joseph, U.E.; Toluwase, A.O.; Kehinde, E.O.; Omasan, E.E.; Tolulope, A.Y.; George, O.O.; Zhao, C.S.; Wang, H.Y. Effect of biochar on soil structure and storage of soil organic carbon and nitrogen in the aggregate fractions of an Albic soil. Arch. Agron. Soil Sci. 2019. [CrossRef]

11. Zhou, H.; Fang, H.; Zhang, Q.; Wang, Q.; Chen, C.; Mooney, S.J.; Peng, X.; Du, Z. Biochar enhances soil hydraulic function but not soil aggregation in a sandy loam. Eur. J. Soil Sci. 2019, 70, 291-300. [CrossRef]

12. Heikkinen, J.; Keskinen, R.; Soinne, H.; Hyväluoma, J.; Nikama, J.; Wikberg, H.; Källi, A.; Siipola, V.; Melkior, T.; Dupont, C.; et al. Possibilities to improve soil aggregate stability using biochars derived from various biomasses through slow pyrolysis, hydrothermal carbonization, or torrefaction. Geoderma 2019, 344, 40-49. [CrossRef]

13. Joseph, S.; Camps-Arbestain, M.; Lin, Y.; Munroe, P.; Chia, C.; Hook, J.; Van-Zwieten, L.; Kimber, S.; Cowie, A.; Singh, B. An investigation into the reactions of biochar in soil. Soil Res. 2010, 48, 501-515. [CrossRef]

14. Ye, L.L.; Wang, C.H.; Zhou, H.; Peng, X.H. Effects of rice straw-derived biochar addition on soil structure stability of an ultisol. Soils 2012, 44, 62-66.

15. Li, W.; Dai, Z.; Zhang, G.X.; Liu, Y.; Han, J. Combination of biochar and nitrogen fertilizer to improve soil aggregate stability and crop yield in Lou soil. J. Plant Nutr. Fertil. 2019, 25, 782-791.

16. Yuan, J.J.; Tong, Y.A.; Lu, S.H.; Yuan, G.J. Biochar and nitrogen amendments improving soil aggregate structure and jujube yields. Trans. Chin. Soc. Agric. Eng. 2018, 34, 159-165.

17. Hou, X.N.; Li, H.; Zhu, L.B.; Han, Y.L.; Tang, Z.; Li, Z.F.; Tang, J.F.; Zhang, S.Q. Effects of biochar and straw additions on lime concretion black soil aggregate composition and organic carbon distribution. Sci. Agric. Sin. 2015, 48, 705-712.

18. Teng, Q.; Hu, X.F.; Luo, F.; Cheng, C.; Ge, X.Y.; Yang, M.Y.; Liu, L.M. Influences of introducing frogs in the paddy fields on soil properties and rice growth. J. Soils Sediments 2016, 16, 51-61. [CrossRef]

19. Liu, K.L.; Han, T.F.; Huang, J.; Huang, Q.H.; Li, D.M.; Hu, Z.H.; Yu, X.C.; Muhammad, Q.; Ahmed, W.; $\mathrm{Hu}, \mathrm{H} . W . ;$ et al. Response of soil aggregate-associated potassium to long-term fertilization in red soil. Geoderma 2019, 352, 160-170. [CrossRef] 
20. Kabiri, V.; Raiesi, F.; Ghazavi, M.A. Six years of different tillage systems affected aggregate-associated SOM in a semi-arid loam soil from Central Iran. Soil Tillage Res. 2015, 154, 114-125. [CrossRef]

21. Chun, Y.; Sheng, G.Y.; Cary, T.C.; Xing, B.S. Composition and sorptive properties of crop residue-derived chars. Environ. Sci. Technol. 2004, 38, 4649-4655. [CrossRef] [PubMed]

22. Bai, N.; Zhang, H.; Li, S.; Zheng, X.; Zhang, J.; Zhang, H.; Zhou, S.; Sun, H.; Lv, W. Long-term effects of straw and straw-derived biochar on soil aggregation and fungal community in a rice-wheat rotation system. PeerJ 2019, 6, e6171. [CrossRef] [PubMed]

23. Pituello, C.; Francioso, O.; Simonetti, G.; Pisi, A.; Torreggiani, A.; Berti, A.; Morari, F. Characterization of chemical-physical, structural and morphological properties of biochars from biowastes produced at different temperatures. J. Soils Sediments 2015, 15, 792-804. [CrossRef]

24. Bailey, V.L.; Fansler, S.J.; Smith, J.L.; Bolton, H., Jr. Reconciling apparent variability in effects of biochar amendment on soil enzyme activities by assay optimization. Soil Biol. Biochem. 2011, 43, 296-301. [CrossRef]

25. Kumara, N.; Nath, C.P.; Hazra, K.K.; Das, K.; Venkatesh, M.S.; Singh, M.K.; Singh, S.S.; Praharaj, C.S.; Singh, N.P. Impact of zero-till residue management and crop diversification with legumes on soil aggregation and carbon sequestration. Soil Tillage Res. 2019, 189, 158-167. [CrossRef]

26. Busscher, W.; Novak, J.; Evans, D.; Watts, D.; Niandou, M.; Ahmedna, M. Influence of peacan biochar on physical properties of a Norfolk loamy sand. Soil Sci. 2010, 175, 10-14. [CrossRef]

27. Choudhury, S.G.; Srivastava, S.; Singh, R.; Chaudhari, S.K.; Sharma, D.K.; Singh, S.K.; Sarkar, D. Tillage and residue management effects on soil aggregation, organic carbon dynamics and yield attribute in rice-wheat cropping system under reclaimed sodic soil. Soil Tillage Res. 2014, 136, 76-83. [CrossRef]

28. Ukalska-Jaruga, A.; Debaene, G.; Smreczak, B. Dissipation and sorption processes of polycyclic aromatic hydrocarbons (PAHs) to organic matter in soils amended by exogenous rich-carbon material. J. Soils Sediments 2019. [CrossRef]

29. Gao, L.L.; Wang, B.S.; Li, S.P.; Wu, H.J.; Wu, X.P.; Liang, G.P.; Gong, D.Z.; Zhang, X.M.; Cai, D.X.; Degré, A. Soil wet aggregate distribution and pore size distribution under different tillage systems after 16 years in the Loess Plateau of China. Catena 2019, 173, 38-47. [CrossRef]

30. Dekemati, I.; Simon, B.; Vinogradov, S.; Birkás, M. The effects of various tillage treatments on soil physical properties, earthworm abundance and crop yield in Hungary. Soil Tillage Res. 2019, 104334. [CrossRef]

31. Pardo, M.T.; Giampaolo, S.; Almendros, G. Effect of cultivation on physical speciation of humic substances and plant nutrients in aggregate fractions of crusting soil from Zimbabwe. Biol. Fertil. Soils 1997, 25, 95-102. [CrossRef]

32. Karami, A.; Khavazi, K. Determination of agricultural sulfur effects on the soil structure using fractal geometery and aggregate stability indices. J. Water Soil Sci. 2019, 23, 267-280. [CrossRef]

33. Jin, Z.W.; Chen, C.; Chen, X.M.; Jiang, F.; Hopkins, I.; Zhang, X.L.; Han, Z.Q.; Billy, G.; Benavides, J. Soil acidity, available phosphorus content, and optimal biochar and nitrogen fertilizer application rates: A five-year field trial in upland red soil, China. Field Crop. Res. 2019, 232, 77-87. [CrossRef]

(C) 2019 by the authors. Licensee MDPI, Basel, Switzerland. This article is an open access article distributed under the terms and conditions of the Creative Commons Attribution (CC BY) license (http://creativecommons.org/licenses/by/4.0/). 